\title{
If Papillomavirus Found Universally in Epidermal Tissues, what does that Mean if a PCR Pap Test is Positive?
}

\author{
Craig G. Burkhart ${ }^{*}, 1$ and Craig N. Burkhart ${ }^{2}$ \\ ${ }^{1}$ University of Toledo College of Medicine, USA \\ ${ }^{2}$ University of North Carolina at Chapel Hill, Chapel Hill, North Carolina, USA
}

\begin{abstract}
Present evidence infers that if degenerate consensus polymerase chain reaction sets were available to amplify all human papillomavirus (HPV) types found in skin, the virus would be found universally in all human epithelia skin. This explains existence of two or more HPV types found in verruca vulgaris, and presence of genital HPV carriage in virgins. HPV colonization probably offers some protective properties to the host.

With the development of real-time polymerase chain reaction and mRNA testing for cervical neoplasia, a question remains as to clinical significance of a positive smear in the absence of clinical disease. In summary, if there is only one genotype of virus present on Pap smear, this is totally normal and there may be no pathology to address.
\end{abstract}

There remains a lot more to learn about warts and more understanding of wart pathogenesis is warranted. For example, the 'infective' nature of this virus needs clarification as human papillomavirus (HPV) can establish latent residence in normal epithelia and in lymphocytes with no clinical sign of disease [1]. HPV can exist as a commensal without causing any detectable existence or can be lead to a verrucous structure. There are hundreds of different HPV viruses and infections will vary based on site, which specific viruses are present, and the host immune response. HPV can cause other skin lesions like cysts in addition to verrucous matter [2]. Moreover, if degenerate consensus polymerase chain reaction sets were available to amplify all of the HPV types found in skin, HPV would likely be found universally in all human epithelia skin $[1,3]$. Thus, all humans have HPV colonization of their skin, and it occurs very early in life [1]. Most likely, the virus is transmitted via amniotic fluid, by means of passage through an infected birth canal, or from personal skin contact shortly after delivery [1].

In summary, humans have a distinct skin genotype of papillomavirus on the surface that may have some 'protective' features. With normal environmental exposures, other types of viral warts can potentially infiltrate the skin via exogenous sources, and the normal host defenses may not block their survival on the surface. This explains:

1. detection of two of more HPV types in $95 \%$ of actual wart tissue on epidermal tissues [4].

2. presence of genital HPV carriage in virgins $[5,6]$.

3. multiple genotypes of human papillovirus reported in over $60 \%$ of cervicovaginal specimens $[7,8]$.

*Address correspondence to this author at the University of Toledo School of Medicine, 5600 Monroe Street, Suite 106B, Sylvania, OH 43560, USA; Tel: 419-885-3403; Fax: 419-885-3401; E-mail: cgbakb@aol.com
The full complexity of the relationship between warts and their human hosts is not fully appreciated at present. One could conjecture that there may be a symbiotic relationship. The warts may find a site of ample nutrients for survival, while human hosts may be rewarded with some basic protection against the environment, which would include more toxic papillomaviruses [1]. The various types of HPV differ in virulence, antigenic properties, and sites of predilection in the host. Additional factors contributing to the development of the actual wart tissue include the pathogenecity and virulence of HPV and the state of the defenses of the host. Moreover, an individual could develop verruca vulgaris either from a failure to control his/her endogenous warts or by invasion by an exogenous HPV.

With the development of real-time polymerase chain reaction and mRNA testing for cervical neoplasia, a question remains as to clinical significance of a positive smear in the absence of clinical disease. Our point is if there is only one genotype of virus present on the Pap smear, there may be no pathology to even address.

\section{REFERENCES}

[1] Burkhart CG. The endogenous, exogenous, and latent infections with human papillomavirus. Int J Dermatol 2004; 43: 548-9.

[2] Ramagosa R, deVilleirs EM, Fitzpatrick JE, Dellavalle RP. Human papillomavirus infection and UV exposure as epidermoid inclusion cyst risk factors in patient with epidermodysplasia verruciformis. J Am Acad Dermatol 2008; 58: S68.e1-S69.e6.

[3] Astori G, Lavergne D, Benton C. Human papillomavirus are commonly found in normal skin of immunocompetent hosts. J Invest Dermatol 1998; 110: 752-5.

[4] Harwood CA, Spink PJ, Surentheran T. Degenerate and nested PCR: a highly sensitive and specific method for detection of human papillomavirus infection in cutaneous warts. J Clin Microbiol 1999; 37: $3545-55$

[5] Frega A, Cenci M, Stentella P. Human papillomavirus in virgins and behavior at risk. Cancer Lett 2003; 194: 21-4. 
[6] Powell J, Strauss S, Gray J. Genital carriage of human papilloma virus DNA in prepubertal girls with and without vulval disease. Pediatr Dermatol 2003; 20: 191-4.

[7] Gomez-Roman JJ, Echevarria C, Salas S, et al. A type-specific study of human papillomavirus prevalence in cervicovaginal samples in three different Spanish regions. APMIS 2009; 117: 22-7.
[8] Mejlhede N, Bonde J, Fomsgaard A. High frequency of multiple HPV types in cervical specimens from Danish women. APMIS 2009; 117: 108-14.

Received: February 26, 2009

Revised: March 3, 2009

Accepted: March 9, 2009

(C) Burkhart and Burkhart; Licensee Bentham Open.

This is an open access article licensed under the terms of the Creative Commons Attribution Non-Commercial License (http://creativecommons.org/licenses/by$\mathrm{nc} / 3.0 /$ ) which permits unrestricted, non-commercial use, distribution and reproduction in any medium, provided the work is properly cited. 